\title{
emeraldinsight
}

\section{On the Horizon}

Emancipatory education and the preparation of future teachers

Eny Winarti,

\section{Article information:}

To cite this document:

Eny Winarti, (2018) "Emancipatory education and the preparation of future teachers", On the Horizon, https://

doi.org/10.1108/OTH-08-2017-0068

Permanent link to this document:

https://doi.org/10.1108/OTH-08-2017-0068

Downloaded on: 02 August 2018, At: 20:08 (PT)

References: this document contains references to 19 other documents.

To copy this document: permissions@emeraldinsight.com

\section{For Authors}

If you would like to write for this, or any other Emerald publication, then please use our Emerald for Authors service information about how to choose which publication to write for and submission guidelines are available for all. Please visit www.emeraldinsight.com/authors for more information.

\section{About Emerald www.emeraldinsight.com}

Emerald is a global publisher linking research and practice to the benefit of society. The company manages a portfolio of more than 290 journals and over 2,350 books and book series volumes, as well as providing an extensive range of online products and additional customer resources and services.

Emerald is both COUNTER 4 and TRANSFER compliant. The organization is a partner of the Committee on Publication Ethics (COPE) and also works with Portico and the LOCKSS initiative for digital archive preservation.

*Related content and download information correct at time of download. 


\title{
Emancipatory education and the preparation of future teachers
}

\author{
Eny Winarti
}

\begin{abstract}
Purpose - The purpose of this paper is to explore the possibilities and impact of emancipatory education in the preparation of future elementary school teachers.

Design/methodology/approach - To serve the purpose of the study, emancipatory education was introduced to the student teachers of an elementary school teacher education program in the Curriculum and Learning Development course. The researcher then observed them during their learning activities and analyzed their portfolios providing feedback during their poster presentations. A classroom experiential model was applied.

Findings - The results of the students' activities indicated that most of the students were able to develop the twenty-first century skills needed to conduct the activities and avoid the tendency to follow directions from someone in authority. After the implementation of this study, the student teachers revealed higherorder thinking skills and were also able to develop learning materials and assessments that were appropriate to elementary school pupils. Still, the "old tendencies" (e.g. not thinking out of the box and waiting for direct instructions) sometimes emerged.

Research limitations/implications - The study was applied to a single course in one out of five parallel classes in a university in a particular area in Indonesia, a developing Asian country with a collectivist culture.

Originality/value - This paper exemplifies how learning and teaching activities in a higher education institution in a developing country can be designed to help future teachers prepare themselves to function and teach in a globalized society.
\end{abstract}

Keywords Curriculum, Action research, Elementary schools, Teacher education,

Emancipatory education

Paper type Research paper

Introduction

The speed of globalization phenomena has created an impact not only in the economic, social and political dimensions of human life but also in the area of education (Winarti, 2011). As companies become multinational, people become more mobile and vice versa. This requires schools and teachers to able to accommodate children from various backgrounds and prepare them for life in a complex and diverse world.

Responding to that complexity, the Partnership for 21st Century Skills (www.p21.org/) indicates that the basic knowledge expected by students in this new millennium should include: English language, reading comprehension, writing English, mathematics, science, government/economics, humanities/arts, foreign languages and history/geography. Meanwhile, the applied skills needed are critical thinking/problem solving, oral communication, written communication, teamwork/collaboration, diversity appreciation, information technology application, leadership, creativity/innovation, lifelong learning/self-direction, professionalism/ work ethics and ethics/social responsibility. While these twenty-first century skills are urgently required by the modern students, these requirements are often challenging for future Indonesian teachers studying in elementary school teacher education programs. Years of
Eny Winarti is Doctor at Teacher Training, Universitas Sanata Dharma Fakultas Keguruan dan IImu Pendidikan, Yogyakarta, Indonesia.
Special gratitude goes to Lembaga Penelitian dan Pengabdian pada Masyarakat (Research Center), Elementary School Teacher Education Study Program and Teacher Education Department (PGSD) of Sanata Dharma University, as well as Wahyu Wido Sari, M. Biotech, who through her vision and passion for education made this article possible. 
learning experience under the centralized government has resulted in the students being in the mode of the blue-collar workers' mentality, requiring detailed instructions for every single project (Winarti, 2012).

Being in such a condition, the researcher, who is simultaneously a lecturer with curriculum development responsibilities, was motivated to introduce emancipatory education, which is known to be used widely in developing countries (Gerdes, 1985; Gordon, 1986; Zeuner, 2013), to deal with the gap between the required and the present mode of teaching and learning. This type of liberation education was introduced in the Curriculum and Learning Development course, which is a compulsory subject for future teachers, especially future elementary school teachers known in Indonesia as the student teachers of Pendidikan Guru Sekolah Dasar (PGSD). For a detailed description of this study's theoretical framework, the sections that follow discuss the concepts and goals of emancipatory education and the design of the PGSD Curriculum and Learning Development course. The paper, then, considers research methods, results and discussion and conclusions and recommendations.

\section{Emancipatory education}

The main goal of emancipatory education, advocated by Paulo Freire, Ira Shor and Henry Giroux (Nouri and Sajjadi, 2014), is to play a fundamental role in creating a just and democratic society. Freire (1970), in his Pedagogy of the Oppressed, clearly states that in the unjust society, there are two diametrically opposing sides: the "oppressors" and the "oppressed" between whom the acts of humanization and dehumanization are continuously exchanged and sometimes even reversed. He emphasizes that none can help the oppressed to liberate themselves from the oppressors except the oppressed themselves by transforming their way of thinking and acting. Macedo (1994) continued Freire's legacy of liberation pedagogy by addressing "literacies of power" and suppressing of critical thinking in current education. Emancipatory education, then, provides a means and a venue for socio-political action and change.

In the context of teaching and learning processes, the teacher-student relationship can at times be like the oppressor-oppressed relationship. In Freire's dialogue with Shor and Freire (1987), Freire mentions that the liberation process can be done through liberating dialogue, in which the teachers and students can communicate to reflect on their reality. In such a dialogue, students and teachers obtain a level of conscious awareness of their relationship with the world that allows them to transform their experience and finally liberate themselves. Such a liberation pedagogy is described by Nouri and Sajjadi (2014) as "emancipatory education".

In a more practical way, we can explainthat understanding with the following situation. For example, in Javanese culture, people are taught to obey their teachers and to never interrupt or question anything they say. This tradition provides a potential for teachers to abuse their power when they do not critically understand and constructively use this authority, and as a result, the students might follow whatever they are told without questioning. This obedience stems from the belief that questioning the teachers or people in authority means degrading them, which might lead to students being punished.

Generating a concrete description of liberation pedagogy, Nouri and Sajjadi (2014) underline that the central aims of emancipatory education are:

- a contextualization of social and political processes;

- development and implementation of negotiated curriculum;

- curriculum focus on the students' investigation of everyday, informal and popular culture, as well as historical patterns of power that develop individual subjectivity and identity; 
- teachers' role as the facilitator that helps students transform their world and make political and social reforms; and

- application of learning assessment in an integral way that provides opportunity for both teachers and students to critically analyze and reflect on their knowledge and experience.

Emancipatory education entails methods of teaching and learning that encourage the students to become aware of their individual reality by investigating their daily life. The results of their investigation will expectedly stimulate their questioning of "reality" and propose changes to the status quo. In a more explicit way, Shor (1988) emphasized that to promote critical training, education should be participatory, the materials should present problems for critical inquiry, the pedagogy should be situated, desocializing and democratic, and the course should be interdisciplinary. This is essentially the process of "conscientization".

\section{Curriculum and learning development course}

To get a more detailed picture of how this research study was developed, it is important to know the design features of the PGSD Curriculum and Learning Development course. For this purpose, this section includes the aims and time allocation of the course, the program of study background, the students' background and the current Indonesian Elementary School Curriculum.

In the institution where this research was developed, the PGSD Curriculum and Learning Development course is delivered to undergraduate students at Semester 5, considering that they will have an internship training (Program Pengalaman Lapangan - PPL) at Semester 7. One of the internship programs is planned for Semester 7, when the students are allowed to have PPL at the related elementary schools. One of the goals of the PPL programs is to prepare students to teach elementary school pupils under the supervision of the classroom teachers and the appointed supervising lecturers from PGSD. It is important to underline that to prepare their teaching the students are required to develop a lesson plan and learning materials with appropriate objectives and assessment instruments.

Other information that is important to note is that in an elementary school in the surrounding area, an elementary school teacher is a classroom teacher. This means that an elementary school teacher is not teaching subjects separately from each other, but most of the time, $s$ (he) should teach the integrated subjects thematically (2013 Indonesian Curriculum). Furthermore, when the PGSD students become "real" teachers, their ability to develop a lesson plan (an "instructional curriculum" in this context) becomes one of the professional criteria to determine their ability to teach (Standar Kualifikasi dan Kompetensi Akademik Guru, 2007). This condition requires that the PGSD course and PPL prepare the students for such a condition.

The Curriculum and Learning Development course is aimed at helping the undergraduate students prepare themselves to be an elementary school teacher. By the end of this course, the students are expected to master the concept of curriculum planning procedures and curriculum implementation. The students are also expected to be able to understand the concept of curriculum, learning approaches, models, methods, strategies, materials and media. In addition to that, the students are also required to be able to analyze, reconstruct and modify the curriculum, the learning approaches, models, methods, strategies, materials and media innovatively.

Elementary school teacher education students in this institution are usually from middle class or lower class. Based on the data collected so far, some of them get scholarship support either from the government or from a particular congregation. This entails an obligation to go back to the donor institution by the time they finish their education. It is 
important to note that the schools that the donor institution own range from schools for middle to lower class as well as middle to upper class. Additionally and occasionally, some other PGSD students are relatively financially independent, meaning that they have more options about where to work later.

Because the students of elementary school teacher education are required to have PPL at an elementary school nearby, a description about the curriculum implemented in these schools might help picture the nature of the PGSD Curriculum and Learning Development course, which is at the center of this study. The current curriculum implemented in the surrounding schools is the Indonesian Ministry of Education's Kurikulum 2013 (K-13/Kurtilas, 2013 Curriculum). To implement the curriculum, the government provided Standar Isi (Content Standard), Standar Proses (Process Standard) and Standar Penilaian (Learning Assessment Standard). These standards contain what to teach, how to teach and how to measure the teaching and learning and are listed in Peraturan Menteri Pendidikan Nasional Republik Indonesia No 16 tahun (2007) or National Ministry of Education Regulation (Salinan Lampiran Peraturan Menteri Pendidikan dan Kebudayaan No 21 Tahun, 2016a; Salinan Lampiran Peraturan Menteri Pendidikan dan Kebudayaan No 22 Tahun 2016b; Salinan Lampiran Peraturan Menteri Pendidikan dan Kebudayaan No 23 Tahun 2016c).

\section{Methodology}

As mentioned previously, the purpose of the study was to explore the possibilities and impact of emancipatory education in the preparation of future elementary school teachers. Emancipatory education itself entails methods of teaching and learning that encourage the students and lecturers to become aware of their individual reality by investigating their daily life. This study, therefore, was sustained on an action research methodology according to the four common steps: planning, acting, observing and reflecting.

\section{Planning and acting: the teaching program}

The researcher, a lecturer in the Curriculum and Learning Development course, planned and implemented the teaching program in an undergraduate classroom setting from February until June in the academic year 2015-2016. The classroom included 40 PGSD students ( 3 male students and 37 female students) with different levels of abilities and from different areas of the country, most of them from Java, Indonesia, either from the rural or urban areas with various types of socioeconomic and religious backgrounds.

In the planning step, a Rencana Pembelajaran Semester (Semester Learning Plan) was designed containing learning outcomes, learning materials, learning activities and learning evaluation. The way to design this plan was by following the steps in curriculum development described by Oliva (2009), which covers identifying the learners' needs, formulating the learning objectives, identifying learning materials, identifying learning activities and determining learning evaluation.

The materials developed in the PGSD lesson plans included four main topics - Curriculum Theory, Curriculum Change in Indonesia, Current Curriculum Implementation in Indonesia and Curriculum Development. Curriculum Theory covered the definition of curriculum, types of curriculum, curriculum development, curriculum implementation, curriculum evaluation and curriculum change and aimed to provide knowledge about the dynamics of the curriculum. Curriculum Change in Indonesia considered the curricula that had been used in Indonesia - how they were developed, decided, implemented, evaluated and finally changed - and was offered to contextualize the dynamics of Indonesian education. Current Curriculum Implementation in Indonesia, comprehending 2013 Indonesian curriculum and its implementation, was given to help the students contextualize the challenges they would face as future teachers. In Curriculum Development, the students developed their own curriculum after reflecting upon their field experience. 
The learning activities conducted in the class varied based on the learning objectives and the learning materials. In Curriculum Theory and Curriculum Change in Indonesia, the students were required to make a summary of the main curriculum changes in their country by analyzing them based on concepts developed in Curriculum Theory. In other words, to be able to analyze the curriculum change in Indonesia, the students should understand curriculum theory first, because the curriculum change in Indonesia is presented historically in the form of the sample of curriculum documents, i.e. Kurikulum 2006 and Kurikulum 2013. Their summary could be presented in any form, as a cartoon, a picture or a poem to accommodate the differences in students' learning styles (Denig, 2004). Most of the time, students were accustomed to their teachers in general presenting the materials in the form of lectures instead of letting them learn independently by themselves, and usually after that, the teachers would use traditional evaluation and assess the students' learning by giving them written tests (Guild, 1994). Therefore, this type of activity was meant to develop the students' critical thinking skills, written communication, diversity appreciation, information technology application, leadership, creativity/innovation and self-direction skills.

For the last two topics, the students developed projects. For Current Curriculum Implementation in Indonesia, the students observed and studied learning activities at the school carried out by the elementary school classroom teachers including teaching preparation (which are in line with the implementation of Standar Isi, Standar Proses and Standar Penilaian provided by the government). This activity was integrated with another course in the program of study, namely, student teachers' Program Pengakraban Lingkungan (Probaling, Internship Preparation 1), the actual internship. Integrating the courses in this case helped the student teachers to understand what to focus on when they observed classroom teachers and what to consider when they developed their own lesson plans.

For Curriculum Development, the students were expected to develop their own instructional curriculum (lesson plans and learning materials) based on their reflection of the implementation of the current curriculum in the field. If needed, the students could interview either the teachers or pupils or even both. These activities were meant to develop the students' critical thinking skills, especially problem solving, oral and written communication, leadership, creativity/innovation, self-direction, professionalism/work ethics and ethics/ social responsibility skills.

The results of the student teachers' field study were presented in the form of poster presentations. Instead of having traditional evaluation, poster presentations were selected considering that such kind of learning activities allowed chances for feedback from other learners and not just from the lecturers (Rowe and Ilic, 2009). Another benefit was that this type of activity allowed the learners to update the materials themselves. In addition, this type of assessment activity allowed the students to practice their questioning abilities considering that, in general, Indonesian students are trained very less to ask questions and share innovative ideas with their teachers and peers. This type of activity was selected after discussion and negotiation with the students at the beginning of the semester, which reflects another important point of emancipatory education.

\section{Observing and reflecting: data collection and analysis}

To observe the implementation of the teacher education program, the researcher took personal notes during and after her teaching. The anecdotal reports contained how the student teachers responded to the learning activities and what challenges were met by either the researcher or the student teachers. In addition, the researcher also collected the student teachers' assignments, such as the summary of Curriculum Change in Indonesia, reports on Current Curriculum Implementation in Indonesia and the project of Curriculum Development. These sources became the main data to understand the impact of the implementation of the emancipatory education program in assisting the student teachers to 
be more adaptable and responsive to their surroundings. When needed, further interviews were also conducted.

Based on the data collected from the anecdotal reports and students' assignments, and using thematic analysis of the values of emancipatory education, namely, manifestation of humanization, critical conscientization and development of problem-solving skills, the researcher then analyzed and reflected on the impact of emancipatory education in the preparation of future teachers. The following section presents and discusses the results of this analysis.

\section{Results and discussion}

\section{Manifestation of humanization}

The manifestation of humanization, which is defined as the awareness of a personal relationship with a bigger world by Nouri and Sajjadi (2014), could be seen in the forms of summary that the students made, which varied based on the students' interests. One of the students, for example, decided to make a summary in the form of a cartoon. All students usually made the summary in the form of note taking without considering their talent and ability. It is important to note that in a collective community, a person has the tendency to cover up their interests or opinion so that they appear to be the same as the others. This innovation indicated that this type of learning provided chances for the students to express their talent. The content guidelines seemed to become the direction for the students about what to put in the summary. The benefits of this type of learning assessment were that the students became more independent in making their summary. None of the students had an exactly similar summary. This emancipatory and participatory approach had the potential for the students to practice higher-order thinking skills, which involved critical thinking with deeper understanding.

Another manifestation of humanization appeared mostly when the students considered the background of the pupils in determining the learning materials and activities in the curriculum. For example, although PGSD students developed the same theme in the curriculum - "trash" - some students could capture that the way to treat the trash could be different from place-to-place depending on the context of the pupils. This at the same time stimulated students' critical conscientization.

\section{Critical conscientization}

The challenges for the students appeared in the second and the third assignments, namely, the study on the implementation of the current curriculum in Indonesia and students' curriculum development, where the researcher found that the students in general still had problems in writing a report. The tendency to use judgmental words still appeared in the reports. For example, the students expressed that guru tidak memperhatikan latar belakang siswa (teachers did not consider the pupils' background). When the students were confronted with the way they described the elementary school classroom teachers, they failed to explain scientifically how they could arrive at such a conclusion. Based on the interviews, the confrontation helped the students to become more aware of the potentially negative effects of not accurately presenting the details to others with sufficient justification and explanation.

Another challenge was related with curriculum development. The students still had a challenge to use operational words in generating Kompetensi Inti (main competencies) and Kompetensi Dasar (basic competencies) into learning indicators. For example, most of the students still used the word memahami [understanding], which is unobservable and unmeasurable. In addition, the students also had the tendency of using lower-level thinkingorder verbs such as menyebutkan [mention], regardless of the basic competencies 
required in the study. Even the word menunjukkan, which is taken from Bloom's taxonomy and should mean "identify", was used as "show", which is at the same level as the word "memorize." As a result, they provided the idea of menunjukkan that they claimed as "identify" with "show" learning activities, which is at remembering level. This pattern resulted in failure to select appropriate activities that directed the learners to obtain the basic competencies required. As a further result, this gap also caused failure to develop a valid and reliable learning assessment instrument. These findings helped the researcher to realize that the PGSD students still had not understood the relevance of writing appropriate learning objectives.

To respond to such a challenge, the researcher decided to provide extra materials especially related with the introduction of word choices that they might use in developing higher-order levels of critical thinking indicators. The researcher also introduced them to a more comprehensive learning assessment by explaining that in the context of learning practice, in which the learning assessment was considered as formative evaluation, it was not necessary to have one activity for only one of the learning indicators. It was possible that one type of learning assessment captured more than one of the learning indicators.

Another example of critical conscientization appeared in the learning activities chosen in the development of the curriculum. Still focused on the theme of "trash", the students' activities in the village were different from the ones developed by the students living near the market. It appeared that such kind of activities proposed a problem-solving activity, which was applicable in their daily life.

It was unavoidable that some students had the tendency to use the old style of curriculum development. Some students did not go through any needs analysis. Instead of considering the students' background, they used their own mindset to work on needs analysis. For example, one of the students was required to teach in a relatively middle to high class elementary school, in which the children's parents did not have enough space for gardening. While the PGSD student teachers had been able to identify the children's background, instead of leading the children to think about an alternative garden, the students introduced the need to have a garden and how to garden in a regular way without any regard to the children's actual situation.

\section{Development of problem-solving skills}

The development of problem-solving skills could be seen in the students' efforts in designing their curriculum development projects. One student developed learning activities that introduced elementary school students to artwork using materials that cannot be recycled such as plastic bags, plastic bottles and plastic containers that can be sold. Some students found alternative materials which were kids friendly, such as mixing tapioca flour with wet unused pieces of papers to make play dough.

Another student designed an elementary students' science experience project using Tapak Dara [Catharantus roseus] leaves to replace Cassava leaves. Further, she explained that her reason to use Tapak Dara was that she wanted to protect Cassava. Despite the fact that everytime we take the leaves of cassava, its roots become bigger, the reason she presented indicated the development of problem-solving skills.

\section{Conclusions}

After analyzing the data, the researcher concluded that emancipatory education had the potential to help the PGSD students shift their approaches from the old mode of learning and teaching to being more sensitive and responding to the challenges of teaching and learning in the twenty-first century. The learning activities with the three main projects in the PGSD Curriculum and Learning Development course helped the students to develop critical 
thinking skills including: problem solving, oral communication, written communication, teamwork/collaboration, diversity, information technology application, leadership, creativity/ innovation, lifelong learning/self-direction, professionalism/work ethics and ethics/social responsibility. Although some "old tendencies" still emerged, the PGSD students became more aware of what they did out of habit and what more they could do.

\section{Recommendations}

Considering that emancipatory education has the potential to help the students respond to the challenges of teaching and learning in the twenty-first century, it is the researcher's recommendation that emancipatory education should be implemented in other courses in developing countries such as Indonesia. Emancipatory education has stimulated the researcher as a lecturer to go beyond "teaching to the test" in the course content and to start teaching for higher-order thinking skills. This type of skills will help future teachers to better respond to what is happening in their surroundings, especially in response to the elementary students they will be teaching. It cannot be avoided though that these new teachers need time and courage to change. There is no study yet about how these student teachers will keep cultivating their ideas when they become "actual" teachers. Therefore, further studies are needed to see the dynamics of these students in their future teaching methods and practices.

\section{References}

Denig, S.J. (2004), "Multiple intelligences and learning styles: two complementary dimensions", Teachers College Record, Vol. 106 No. 1, pp. 96-111.

Freire, P. (1970), Pedagogy of the Oppressed, Continuum Books, New York, NY.

Gerdes, P. (1985), "Conditions and strategies for emancipatory mathematics education in undeveloped countries", For the Learning of Mathematics, Vol. 5 No. 1, pp. 15-20.

Gordon, B.M. (1986), "The use of emancipatory pedagogy in teacher education", The Journal of Educational Thought, Vol. 20 No. 1, pp. 59-66.

Guild, P. (1994), "The culture/learning style connection", Educational Leadership, Vol. 51 No. 8 , pp. 16-21.

Macedo, D. (1994), Literacies of Power: What Americans are not Allowed to Know, Westview Press, Boulder, CO.

Nouri, A. and Sajjadi, S.M. (2014), "Emancipatory pedagogy in practice: aims, principles and curriculum orientation", International Journal of Critical Pedagogy, Vol. 5 No. 2, pp. 76-87.

Oliva, P.F. (2009), Developing the Curriculum, 7th ed., Pearson Education, Boston, MA.

Peraturan Menteri Pendidikan Nasional Republik Indonesia No 16 Tahun (2007), Tentang Kualifikasi Akademik dan Kompetensi Guru [Regulation of the Minister of National Education of the Republic of Indonesia No. 16 of 2007 on Academic Qualifications and Teacher Competencies].

Rowe, N. and Ilic, D. (2009), "What impact do posters have on academic knowledge transfer? A pilot survey on author attitudes and experiences", BMC Medical Education, Vol. 9 No. 1, pp. 1-7.

Salinan Lampiran Peraturan Menteri Pendidikan dan Kebudayaan No 21 Tahun (2016a), Tentang Standar Isi Pendidikan Dasar dan Menengah [Copy of Attachment to Regulation of the Minister of Education and Culture No. 21 of 2016 on Basic Content of Basic and Intermediate Education].

Salinan Lampiran Peraturan Menteri Pendidikan dan Kebudayaan No 22 Tahun (2016b), Tentang Standar Proses Pendidikan Dasar dan Menengah [Copy of Attachment to Regulation of the Minister of Education and Culture No. 22 of 2016 on Basic Content of Basic and Intermediate Education].

Salinan Lampiran Peraturan Menteri Pendidikan dan Kebudayaan No 23 Tahun (2016c), Tentang Standar Penilaian Pendidikan [Copy of Attachment to Regulation of the Minister of Education and Culture No. 23 of 2016 on Basic Content of Basic and Intermediate Education]. 
Shor, I. (1988), "Working hands and critical minds: a Paulo Freire model for job training", The Journal of Education, Vol. 170 No. 2, pp. 102-121.

Shor, I. and Freire, P. (1987), "What is the 'dialogical method' of teaching?", The Journal of Education, Vol. 169 No. 3, pp. 11-31.

Winarti, E. (2011), "School-based management: the challenges of its implementation in Indonesia", Orientasi Baru: Jurnal Filsafat dan Teologi, Vol. 20 No. 1, pp. 85-106.

Winarti, E. (2012), School-Level Curriculum: Learning from a Rural School in Indonesia, (Doctoral Dissertation), Ohio University, Ohio.

Zeuner, C. (2013), "From workers' education to societal competencies: approaches to a critical, emancipatory education for democracy", European Journal for Research on the Education and Learning of Adults, Vol. 4 No. 2, pp. 139-152.

\section{Further reading}

Partnership for 21st Century Learning (www.p21.org/).

\section{Corresponding author}

Eny Winarti can be contacted at: enywinarti@usd.ac.id

For instructions on how to order reprints of this article, please visit our website: www.emeraldgrouppublishing.com/licensing/reprints.htm

Or contact us for further details: permissions@emeraldinsight.com 